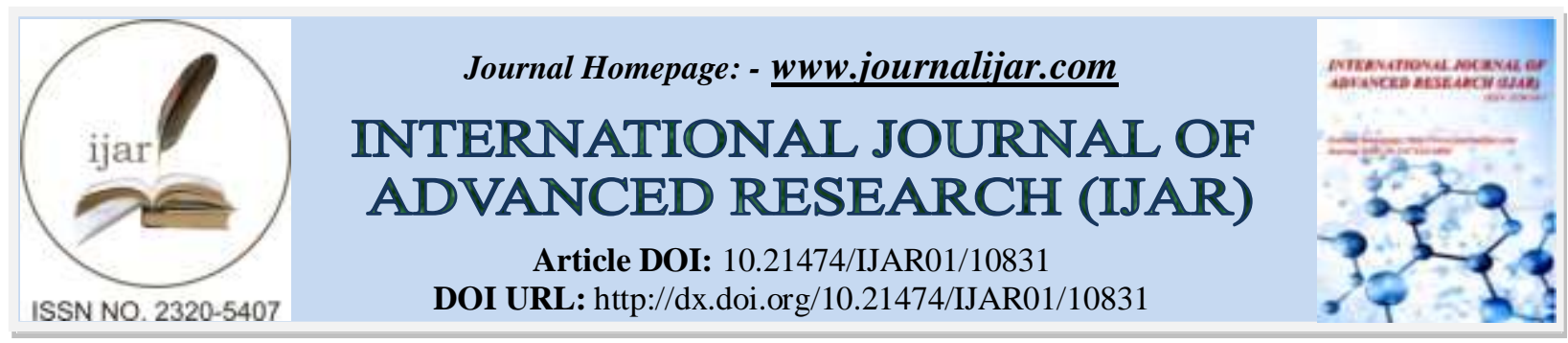

RESEARCH ARTICLE

\title{
OBSERVATIONAL STUDY TO ASSESS THE STATUS OF OJUS IN ASTHMA INDIVIDUALS
}

\author{
Fousiya TP ${ }^{1}$, Dr. Hakkeempanthapulan ${ }^{2}$ and Dr. Anjali Sivaram ${ }^{3}$ \\ 1. PG Scholar, Department of Kriya Sareera, GAVC Kannur, Kerala, India. \\ 2. Assistant professor ,Department of Kriya sareera, Govt Ayurveda College, Kannur, kerala, India. \\ 3. Associate professor, Department of Kriya Sareera, Govt Ayurveda college, Kannur, Kerala, India.
}

\section{Manuscript Info}

.a.n....................

Manuscript History

Received: 14 February 2020

Final Accepted: 16 March 2020

Published: April 2020

Key words:-

Ojus, Asthma

\section{Abstract}

Asthma is an obstructive lung disease affecting > 230 million people worldwide and a significant cause of morbidity in patients of all ages. It is a heterogenous disease with a complex pathophysiology and phenotype. The condition is characterised by variable airflow obstructionand airway hyper responsiveness. Understanding the severity of the disease is important, and treatment is aimed at symptom control and the prevention of future exacerbations. In Ayurveda classics lakshanas of swasa are closely related to ojakhaya lakshana.

According to Ayurveda, ojus is a essence present in every dhatu and considered as sara of all the seven dhatus starting from rasa to shukraand responsible for the strength of the body. Ojus is one of most important element for maintains and sustaining of life. All human beings are well nourished by ojus and its decrease leads to cessation of life. In Ayurveda ojus is also known as bala (strength) because it provides strength to the body in terms of physical, mental, immunological and resistance to the body.

Copy Right, IJAR, 2020,. All rights reserved.

\section{Introduction:-}

Asthma is defined as a disorder characterised by chronic airway inflammation and increased airway responsiveness resulting in symptoms of wheeze, cough, chest tightness and dyspnoea. It is characterised functionally by the presence of airflow obstruction which is over short periods of time or is reversible with treatment. It is not a uniform disease but rather a dynamic clinical syndrome which has a number of clinical patterns. Many patients with well controlled asthma are asymptomatic with normal lung function between exacerbations, although even these patients have evidence of chronic airway inflammation and hyperresponsiveness. By contrast, in some patients with chronic asthma the asthma progresses, leading to irreversible obstruction of the airways. According to Ayurveda asthma related to swasa. In swasa lakshana 'nashtachaya' is similar to ojakshaya lakshana like 'duchaya'.So ojakshayalakshanas can be seen in asthma patients. No previous studies was found to correlate asthma with ojus status. So in this study show the relation between asthma and status of ojus.

\section{Prevalence:}

Asthma is common and its prevalence is increasing. Studies using objective measurements of lung function, airway responsiveness and symptoms suggest that about $7 \%$ of adults and up to $15 \%$ of children in the UK have asthma. There is considerable interest in the reasons for the increase in the prevalence of asthma, most probably relating to changes in the indoor environment including early exposure to air allergens and cigarette smoke, fewer childhood 
infections and changes in diet. There is a wide variability in the geographical prevalence of asthma, with the highest rates observed in New Zealand, Australia and the UK, and the lowest in countries such as China and Malaysia.

\section{Pathophysiology:}

Asthma is multifactorialin origin, arising from the interaction of both genetic and environmental factors. Airway inflammation characterising asthma occurs when genetically susceptible are exposed to environmental factors, but the exact processes may vary from patient to patient, the timing, intensity and mode of exposure to aero-allergens are important environmental factors which stimulate the production of IgE.

\section{Genetic susceptibility:}

It has long been known that asthma and atopy run in families. Asthma which begins in childhood generally occurs in atopic individuals who produce significant amounts of IgE on exposure to small amounts of common antigens. This contrasts with those patients who develop asthma in adult life and who are non atopic, so called intrinsic or late onset asthma, first degree relatives of asthmatic patients have a higher prevalence of asthma when compared to relatives of non asthmatic patients. Atopic individuals demonstrate positive reactions to antigens delivered in skin prick tests and have a higher prevalence of asthma, allergic rhinitis, urticarial and eczema. Several potential gene linkages (eg; chromosome to asthma and atopy have been suggested; however, the genetic contribution to asthma remains poorly defined. It possibly involves polygenic inheritance with several genes contributing to the asthmatic tendency in any one individual, and genetic heterogeneity where different combinations of genes lead to asthma in different individuals.

\section{Environmental factors: \\ Indoor:}

Indoor environment is a particularly important cause of asthma in children since allergen exposure early in life appears to be important in determining sensitisation. House dust mites abount in carpets, soft furnishings and bedding, and pet derived allergens are wide spread in houses where dogs or cats are kept. Other allergens of relevance are fungal spores and cockroach antigens. Pollutants such as nitrogen dioxide are found in higher concentrations indoors than outside as a result of gas cookers. Sulphur dioxide and particulate pollutants are released from open fires. Passive exposure to cigarette smoke immediately following birth increases the risk of developing asthma.

\section{Outdoor:}

Nitrogen dioxide, ozone, sulphur dioxide and airborn particulates exacerbate asthma symptoms.

Work; many agents encountered in the work place may induce occupational asthma, eg.isocyanates, epoxy resins and wood dust.

\section{Drugs:}

Beta blockers can induce bronchoconstriction even when administered in the form of eye drops.Hence beta blockers should be avoided in patients with asthma or COPD.

\section{Infections:}

Many viral and bacterial infections of the respiratory system produce a transient increase in airway responsiveness in asthmatic patients. Viruses in particular are an important cause of asthma exacerbations.

\section{Smoking:}

Smoking during pregnancy is thought to increase the risk of developing atopic disease in infancy and passive exposure to smoking has an adverse effect on asthma and other respiratory diseases.

\section{Anxiety and psychosocial factors:}

Any cause of severe anxiety or stress can exacerbate asthma, and acute emotion may provoke an acute attack, but there is no evidence that asthmatics are primarily psychologically disturbed.

\section{Clinical features:}

Typical symptoms of asthma comprise wheeze, breathlessness, cough and a sensation of chest tightness. These symptoms may occur for the first time at any age, and may be episodic or persistant. Patients with episodic asthma are usullay asymptomatic between exacerbations, which occur during viral respiratory tract infections or after 
exposure to allergens .this pattern of asthma is commonly seen in children or young adults who are atopic. In other patients the clinical pattern is of persistant asthma with chronic wheeze and breathlessness. This may sometimes make it difficult to distinguish from wheeze due to COPD or more unusual causes, eg. Cardiac failure . This pattern is more common in older patients with adult onset asthma who are non atopic and typifies intrinsic asthma. The variable nature of symptoms is a characteristic feature. Typically, there is a diurnal pattern with symptoms and peak expiratory flow measurement being worse in the early morning. Symptoms such as cough and wheeze often disturb sleep and the term 'nocturnal asthma `emphasises this. Cough may be the dominant symptom and the lack of wheeze or breathlessness may lead to a delay in making the diagnosis of so called 'cough variant asthma'. Symptoms may be specifically provoked by exercise. (exerciseindused asthma). All of these descriptive clinical terms are useful in emphasising the characteristic features of asthma particular to each patient and highlight the fact that asthma is not a uniform static disease but a broad dynamic syndrome.

\section{Acute severe asthma:}

This term has replaced status asthmaticus as a description of life threatening attacks of asthma. Patients are usually extremely distressed, using accessory muscles of respiration, are hyperinflated and tachypnoeic. Respiratory symptoms are accompanied by tachycardia, pulsusparaoxus and sweating. In very severe asthma central cyanosis occurs and airflow may have become so restrictive that rhonchi are no longer produced. The presence of a silent chest and bradycardia in such patients is an ominous sign.

\section{Classification:}

\begin{tabular}{|l|l|l|l|l|l|}
\hline Clinical classification $(\geq 12$ years old) \\
\hline Severity & $\begin{array}{l}\text { Symptom } \\
\text { frequency }\end{array}$ & $\begin{array}{l}\text { Night-time } \\
\text { symptoms }\end{array}$ & $\begin{array}{l}\text { \% FEV } \mathbf{~ o f ~} \\
\text { predicted }\end{array}$ & $\mathbf{F E V}_{\mathbf{1}}$ variability & SABA use \\
\hline Intermittent & $\leq 2 /$ week & $\leq 2 /$ month & $\geq 80 \%$ & $<20 \%$ & $\leq 2$ days/week \\
\hline Mild persistent & $>2 /$ week & $3-4 /$ month & $\geq 80 \%$ & $20-30 \%$ & $>2$ days/week \\
\hline Moderate persistent & Daily & $>1 /$ week & $60-80 \%$ & $>30 \%$ & Daily \\
\hline Severe persistent & Continuously & Frequent (7/week) & $<60 \%$ & $>30 \%$ & $\geq$ twice/day \\
\hline
\end{tabular}

Asthma exacerbation:

\begin{tabular}{|c|c|c|}
\hline \multicolumn{3}{|c|}{ Severity of an acute exacerbation ${ }^{[99]}$} \\
\hline \multirow{3}{*}{$\begin{array}{l}\text { Near-fatal } \\
\text { Life-threatening } \\
\text { (any one of) }\end{array}$} & \multicolumn{2}{|c|}{ High $\mathrm{PaCO}_{2}$, or requiring mechanical ventilation, or both } \\
\hline & Clinical signs & Measurements \\
\hline & Altered level of consciousness & Peak flow $<33 \%$ \\
\hline & Exhaustion & Oxygen saturation $<92 \%$ \\
\hline & Arrhythmia & $\mathrm{PaO}_{2}<8 \mathrm{kPa}$ \\
\hline & Low blood pressure & "Normal" $\mathrm{PaCO}_{2}$ \\
\hline & Cyanosis & \\
\hline & Silent chest & \\
\hline & Poor respiratory effort & \\
\hline \multirow{4}{*}{$\begin{array}{ll}\text { Acute } & \text { severe } \\
\text { (any one of) } & \end{array}$} & \multicolumn{2}{|l|}{\begin{tabular}{|l} 
Peak flow $33-50 \%$ \\
\end{tabular}} \\
\hline & \multicolumn{2}{|l|}{ Respiratory rate $\geq 25$ breaths per minute } \\
\hline & \multicolumn{2}{|l|}{ Heart rate $\geq 110$ beats per minute } \\
\hline & \multicolumn{2}{|l|}{ Unable to complete sentences in one breath } \\
\hline \multirow[t]{3}{*}{ Moderate } & \multicolumn{2}{|l|}{ Worsening symptoms } \\
\hline & \multicolumn{2}{|l|}{ Peak flow $50-80 \%$ best or predicted } \\
\hline & \multicolumn{2}{|l|}{ No features of acute severe asthma } \\
\hline
\end{tabular}

\section{Ojus:}

The one which dwells in the heart and is predominantly white, yellowish and reddish in colour is known as ojus of the body; if the ojus is destroyed, the human beings will also perish. The form in which the theojus is produced in the body of the human beings for the first time is of the colour of ghee; in taste it is like that of honey, in smell it is like that of fried paddy, as the bees collect honey from the fruits and flowers, so the ojus it maintains the body of human being by virtue of its properties and actions. 
The ojus of superior quality is only of eight drops in quantity. The other type of ojus on the other hand is half an Anjali in quantity. This is the quantity of the slaismika type of ojus of sarira.

The ojus is of two types- the superior type and the other ordinary type, heart is the dwelling place for the superior type of ojus. The vessels attached to the heart are the site of other ordinary type. Heart is the dwelling place for the superior type of ojus. The vessels attached to the heart are the site of other ordinary type of ojus. As regards the first category of ojus,its volume is fixed. Any diminution in the volumes would amount to instantaneous death, diminution is however, possible in other type of ojus as it happens in the case of diabetes mellitus. synonyms:deepthi, avasthamba, prakasa, bala,tejus, sarvadhatutejus,kapha,bala,sleshma,rasa,rakta

\title{
Properties of ojus:
}

Aparaojus is also known as slaishmikaojus and it is considered as somatmakam denoting the predominance of Ap and Prthwimahabhootas.

According to susrutamsootram the colour of ojus is suklavarna .Dalhana opines that the colour of ojus is atisweda. According to charakamsootram, the colour of ojus is similar to that of ghee. He also opines that ojus has a red with slight yellow colour. As per Ashtanga sangraham and Ashtanga Hridayam sootram, ojus is a clear substance with a tinge of red and yellow colour.

Dalhana comments on Acharya charakas opinion that by the term` sukla "suddha' is intended here. When ojus is understood in the context of 'sukramoja', it cannot be seen as a separate entity from sukra. Sukra is understood to be the sneha of rasadidhatus and ojus is a part of sukra. The existence of ojus and sukra is close that it is like ghruta and ksheera. Sukra is said to have the colour of taila and kshoudra and thus the colour of ojus as rakta and ishat pita can be justified. Kasyapa mentioned the colour of ojus as syava. As per charakamsootram, ojus smells like laja. According to charakamsootram, ojus tastes like madhu(honey) iemadhura with slight kashaya rasa. While describing the gunas of ojus, charaka states that it is madhura.

Ojus is said to possess all those gunas that are opposite to that of visha. Charaka Samhita explained that these gunas are guru, seta, mrdu,slakshna, Bahala, madhura, sthira, prasanna, pichila, snigdha. In susruta Samhita, gunas such as somatmakam, snigdha, sukla, seta, sthira, sara, viviktha, mrdu, mrrrtsna, uthamapranayatana are given to ojus. Ashtanga hridaya describes ojus as snigdha, somatmaka and sudha. Ashtanga sangraha explained mrdu instead of snigdha. Acharya charaka has used the word ojus for prakrutha kapha as well as for bala.

Signs and symptoms of diminution of ojus is the fear,complex, constant weakness,worry, affliction of sense organs with pain, loss of complexion, cheerlessness,roughness and emaciation.

\section{Materials and Methods:-}

Spirometric values, ojus assessing tool.

Spirometric values are FVC, FEV, PEF, Vmax25, Vmax50, Vmax75.

Ojus assessment tool: The tool was developed in the form of a structured close ended questionnaire. The questionnaire has 37 questions measuring 18 variables under 3 domains and 7 subdomains. Tool for the assessment of status of ojus is analysed in an objective way,grading from from high score to low score is possible. Score 0 to 30 considered as avaraojus and 31 to 60 considered as madyamaojus and above 60 considered as pravaraojus. Any score less than $30 \%$ are likely to have problems pointing towards severe ojakshayam.

\author{
Methodology:- \\ Study design: \\ observational study

\section{Inclusion criteria:} \\ Both sexes \\ Diagnosed cases of asthmatic individuals
}

\section{Exclusion criteria:}

Who are alcohol and tobacco addicts 
Pregnant and lactating woman

Subjects with other systemic illness

Asthmatic individuals age group 30 to 70 who attended the OPD of Govt Ayurveda College hospital, Paryaram were selected based on clinical symptoms and FEVI and PEF valuesetc.(spirometric values). 15 individuals were selected based on this criteria. Then assess the status of ojus using a validated questionnaire developed in the Department of kriyasareera as a part of MD research work. The data was statistically analysed.

\section{Observation and Analysis:-}

In this study out of 15 subjects $40 \%$ are males and $60 \%$ are females. Out of this moderate asthmatic subjects are $73.3 \%$ and severe asthmatic subjects are $26.7 \%$. In this study found that avaramojus is $40 \%$ and madyamaojus is $60 \%$.

Table 1:- Distribution according to sex.

\begin{tabular}{|l|l|l|l|l|l|}
\hline & & Frequency & Percent & Valid Percent & Cumulative Percent \\
\hline \multirow{4}{*}{ Valid } & Male & 6 & 40.0 & 40.0 & 40.0 \\
\cline { 2 - 6 } & Female & 9 & 60.0 & 60.0 & 100.0 \\
\cline { 2 - 6 } & Total & 15 & 100.0 & 100.0 & \\
\hline
\end{tabular}

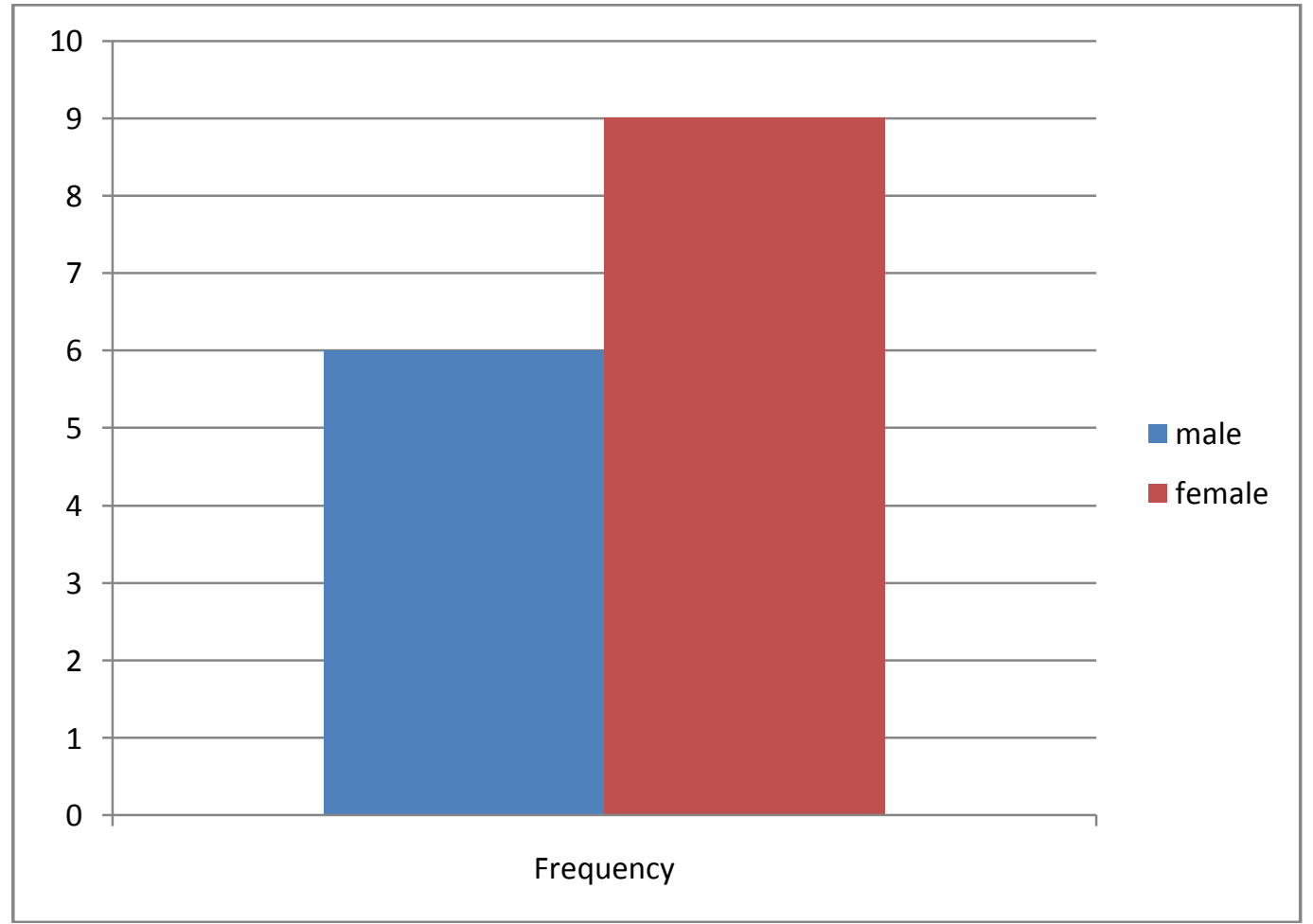

\begin{tabular}{|l|l|l|l|l|l|}
\hline \multicolumn{2}{|l|}{ Asthma status } & Vrequency & Percent & Valid Percent & Cumulative Percent \\
\hline \multirow{3}{*}{ Valid } & moderate & 11 & 73.3 & 73.3 & 73.3 \\
\cline { 2 - 6 } & severe & 4 & 26.7 & 26.7 & 100.0 \\
\cline { 2 - 6 } & Total & 15 & 100.0 & 100.0 & \\
\hline
\end{tabular}




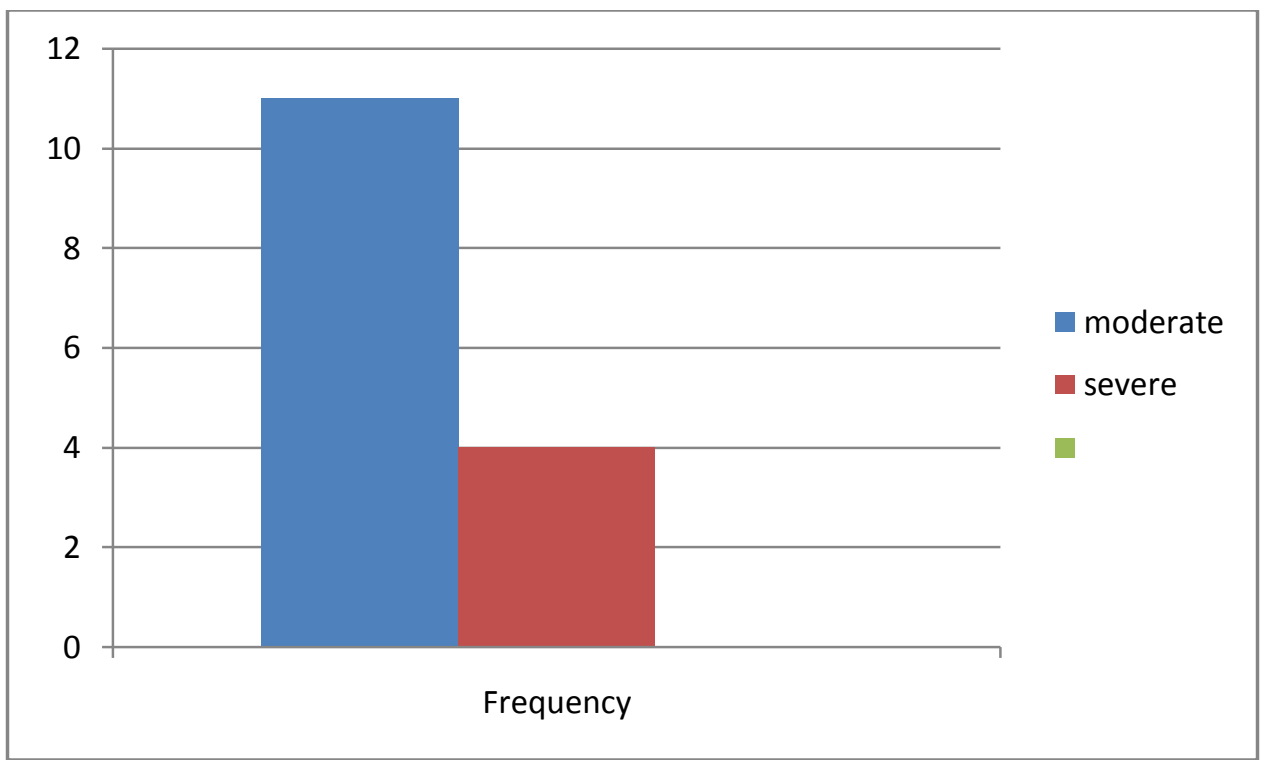

Table 2:- Ojostatus.

\begin{tabular}{|l|l|l|l|l|l|}
\hline & & Frequency & Percent & Valid Percent & Cumulative Percent \\
\hline Valid & avaram & 6 & 40.0 & 40.0 & 40.0 \\
\cline { 2 - 6 } & Madyamam & 9 & 60.0 & 60.0 & 100.0 \\
\cline { 2 - 6 } & Total & 15 & 100.0 & 100.0 & \\
\hline & & & & & \\
\hline & & & & & \\
\hline
\end{tabular}

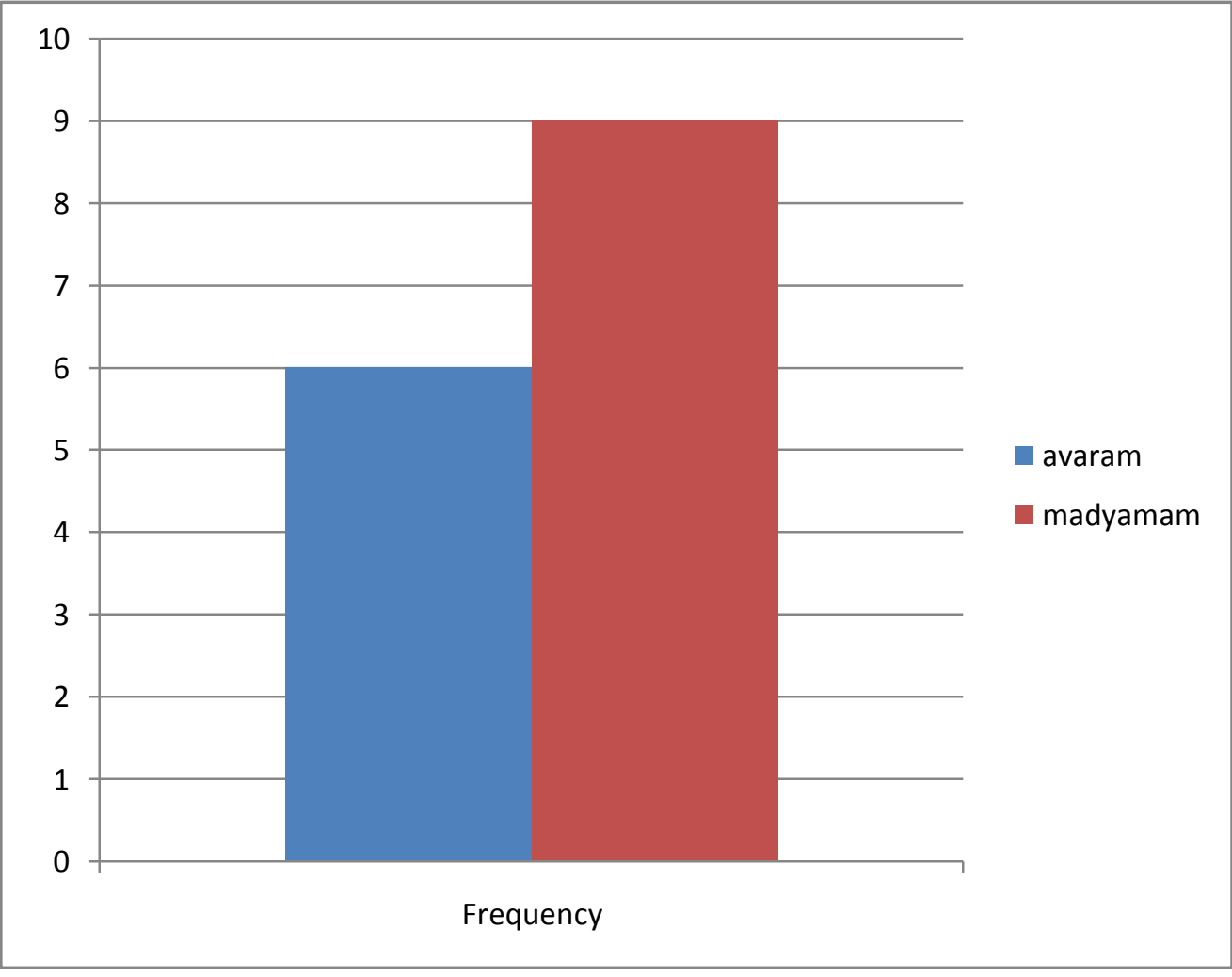




\section{Result:-}

Between score of ojus and FVC was assessed using spearman correlation coefficient is 0.368 and the level of significance was found to be 0.08 . Between score of ojus and FEV was assessed using spearmane`s correlation coefficient is 0.594 and significant at 0.01 level. Between score of ojus and PEFspearman correlation coefficient is 0.698 and significant at 0.01 level. Between score of ojus and Vmax was analysed using spearman correlation coefficient 0.640 and the level of significance was found to be 0.01 . Between ojus score and status of asthma was assessed using spearman correlation coefficient -0.595 and level of significance was found to be 0.01 .

Table 3:- Correlations between fev\&ojus score.

\begin{tabular}{|l|l|l|l|l|}
\hline & & & ojcore & fev0.5 \\
\hline \multirow{3}{*}{ Spearman's rho } & \multirow{4}{*}{ ojcore } & Correlation Coefficient & 1.000 & $.594^{* *}$ \\
\cline { 3 - 5 } & & Sig. (1-tailed) &. & .010 \\
\cline { 2 - 5 } & $\mathrm{N}$ & 15 & 15 \\
\cline { 2 - 5 } & \multirow{3}{*}{ fev0.5 } & Correlation Coefficient & $.594^{* *}$ & 1.000 \\
\cline { 2 - 5 } & Sig. (1-tailed) & .010 &. \\
\cline { 2 - 4 } & $\mathrm{N}$ & 15 & 15 \\
\hline **. Correlation is significant at the 0.01 level (1-tailed). & \\
\hline
\end{tabular}

Table 4:- Correlations between pef\&ojus score.

\begin{tabular}{|c|c|c|c|c|}
\hline & & & Ojcore & Pef \\
\hline \multirow[t]{6}{*}{ Spearman's rho } & \multirow[t]{3}{*}{ ojcore } & Correlation Coefficient & 1.000 & $.698^{* *}$ \\
\hline & & Sig. (1-tailed) & 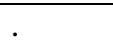 & .002 \\
\hline & & $\mathrm{N}$ & 15 & 15 \\
\hline & \multirow[t]{3}{*}{ pef } & Correlation Coefficient & $.698^{* *}$ & 1.000 \\
\hline & & Sig. (1-tailed) & .002 & \\
\hline & & $\mathrm{N}$ & 15 & 15 \\
\hline
\end{tabular}

Table 5:- Correlations between Vmax25 \&ojus score.

\begin{tabular}{|c|c|c|c|c|}
\hline & & & Ojcore & vmax 25 \\
\hline \multirow{6}{*}{ Spearman's rho } & \multirow[t]{3}{*}{ ojcore } & Correlation Coefficient & 1.000 & $.640^{* * *}$ \\
\hline & & Sig. (1-tailed) & & .005 \\
\hline & & $\mathrm{N}$ & 15 & 15 \\
\hline & \multirow[t]{3}{*}{$\operatorname{vmax} 25$} & Correlation Coefficient & $.640^{* *}$ & 1.000 \\
\hline & & Sig. (1-tailed) & .005 & \\
\hline & & $\mathrm{N}$ & 15 & 15 \\
\hline
\end{tabular}

Table 6:- Correlations between asthma status \&ojus score.

\begin{tabular}{|l|l|l|l|l|}
\hline & & & ojcore & aststatus \\
\hline \multirow{3}{*}{ Spearman's rho } & \multirow{2}{*}{ ojcore } & Correlation Coefficient & 1.000 & $-.595^{* * *}$ \\
\cline { 3 - 5 } & & Sig. (1-tailed) &. & .010 \\
\cline { 2 - 5 } & $\mathrm{N}$ & 15 & 15 \\
\cline { 2 - 5 } & \multirow{2}{*}{ aststatus } & Correlation Coefficient & $-.595^{* *}$ & 1.000 \\
\cline { 3 - 5 } & & Sig. (1-tailed) & .010 &. \\
\cline { 2 - 4 } & $\mathrm{N}$ & 15 & 15 \\
\hline \multirow{2}{*}{$* *$ Correlation is significant at the 0.01 level (1-tailed). } & & \\
\hline
\end{tabular}

Table 7:- Correlations between FVC \&ojus score.

\begin{tabular}{|l|l|l|l|l|}
\hline & & & Fvc & Ojcore \\
\hline Spearman's rho & \multirow{3}{*}{ Fvc } & Correlation Coefficient & 1.000 & .368 \\
\cline { 3 - 5 } & & Sig. (1-tailed) &. & .089 \\
\cline { 2 - 5 } & N & 15 & 15 \\
\cline { 2 - 5 } & ojcore & Correlation Coefficient & .368 & 1.000 \\
\hline
\end{tabular}




\begin{tabular}{|l|l|l|l|l|}
\hline & Sig. (1-tailed) & .089 &. \\
\cline { 3 - 5 } & $\mathrm{N}$ & 15 & 15 \\
\hline
\end{tabular}

\section{Discussion:-}

Swasa is amashayasamudbhavavyadhi. Amashaya is the site of agni. In swasa there is dahatwagnivyapara can be seen. Dhatwagnimandyamalso leads to ojakshaya.In श्वासलक्षण , "नष्टच्छायो " is the symptom. It is similar to ओजक्षयलक्षण like 'दुच्छाय '. In later stages of swasa moreojakshayalakshanas can be seen.As per Charaka prakrutha kapha is more related to ojus. Swasamis due to kaphapitta vitiation. Sokaphapittavitiation eventually leads to ojakshaya.

\section{Conclusion:-}

In this study it was found that asthma lakshnas is closely related to ojakshayalakshanas. More degree of ojakhayalakshanas were found in severe asthma patients.

\section{References:-}

1. Vagbhata, Ashtanga Hridayam. 10thedition. Translated by prof . K.R. Srikantha Murthy, Varanasi: ChaukambhaKrishnadasAcademy ; 2014. A H sutram 11/ 372.

2. Acharya Agnivesa, Charaka Samhita (vol 1) . Reprint edition . Translated by Dr Ram karan Sharma, Vaidya Bhagwan Dash .Varanasi: Chowkamba Sanskrit series Office ; 2015. Charakamsutram 30/9 -11

3. Vagbhata, Ashtanga Hridayam . 10thedition . Translated by Prof.K.R .SrikanthaMurthy, Varanasi: ChaukambhaKrishnadas Academy; 2014 A H nidanam 4/43.

4. Acharya Susruta, Susruta Samhita. Reprint edition . Translated by Prof .K .R .Srikantha Murthy, Varanasi ;ChaukambhaOrientalia ; 2012 . Sus sutram 15/19.

\section{Annexure:}

\section{Ojus assessment questionnaire:}

Are you afraid to have a visit to a hospital?

Always afraid b) sometimes afraid c) never afraid

Do you have the feeling of fear when you are being watched by someone else?

always fears b)sometimes fears c)never fears

Do you feel any anxiety about misfortunes that will befall on you?

always anxious b)sometimes anxious c)never anxious

Do you get tensed about travelling outside alone?

always get tensed b)sometimes get tensed c)never get tensed

Do you have the feel of easy dislocation of joints?

always feel b)sometimes feel c)never feel

6 . Do you feel weary?

always feel b)sometimes feel c)never feel

7. Do you find any difficulty in moving your body?

always feel b)sometimes feel c)never feel

8. Do you feel heaviness in your body?

always feel b)sometimes feel c)never feel

9. Do you feel any change in complexion during the last 6 months?

always feel b)sometimes feel c) never feel

10. Do you feel exhausted even in the beginning of a heavy work?

Always feel b)sometimes feel c) never feel

11. Do you feel lazy always?

Always feel b) sometimes feel c) never feel

12. Do you feel drowsy while doing things?

Always feel b) sometimes feel c) never feel

13. Do you often yawn?

Always yawn b) sometimes yawn c) never yawn

14. Do you feel sleepy even after having a sound sleep?

Always feel b) sometimes feel c) never feel

15. Have you been losing consciousness frequently during the last six months? 
Always lose b) sometimes lose c) never lose

16. Do you feel that your body is getting slim during the last six months?

Always feel b) sometimes feel c)never feel

17. Are you not able to enjoy even joyful moments?

Never able to enjoy b) sometimes able to enjoy c) always able to enjoy

18. Do you feel that your body is dry?

- Always feel b) sometimes feel c) never feel

19. Do you feel that your lips are always dry?

- Always feel b) sometimes feel c) never feel

20. Do you feel thirsty even after drinking enough water?

Always feel b) sometimes feel c) never feel

21 . Do your nails break easily?

Always break easily b) sometimes break easily c)never break easily

22. Do you have hair loss?

Always have b) sometimes have c) never have

23. Do you have constipation

a) Always have b) sometimes have c) never have

24. Does your body have inflammation that appears and disappears abruptly?

Always have b) sometimes have c) never have

25 . Do you feel you don thave the required firmness in your body?

Always feel b) sometimes feel c) never feel

26. Do you feel difficulty in doing daily chores?

Always feel b) sometimes feel c) never feel

27. Can you bend down and straighten up with ease?

Can always bend b) can sometimes bend c) can never bend

28. Do you feel difficulty in lifting even one kilogram weight?

Always feel b) sometimes feel c) never feel

29. Do you have any difficulty while getting up from armless chair?

Always have b) sometimes have c) never have

30. Do you have any difficulty in getting up from bed?

Always have b) sometimes have c) never have

31. During the last six months have you felt having reduced voice while talking?

Always feel b) sometimes feel c) never feel

32. In the past six months have you felt any strain in talking?

always feel b)sometimes feel c)never feel

33. Is your daily routine disturbed due to lack of memory?

Always disturbed b) sometimes disturbed c) never disturbed

34. Do you find any difficulty in taking decisions regarding day today matters?

Always feel difficulty b) sometimes feel difficulty c) never feel difficulty

35. Do you find situations in which you don't remember the tasks to be done one after another?

Always find b) sometimes find c) never find

36. Are you able to pray with concentration?

Always able to b) sometimes able to c) never able to

37. Are you able to do things with concentration?

Always able to b) sometimes able to c) never able to 